\title{
Biological roles of insulin-like growth factor binding proteins (IGFBPs)
}

\author{
Ho-Seong Kim,,$^{1,3}$ Ron G. Rosenfeld ${ }^{2}$ and \\ Youngman $\mathrm{Oh}^{2}$ \\ 1 Department of Pediatrics, College of Medicine, \\ Ewha Womans University, Seoul 158-056, Korea \\ 2 Department of Pediatrics, School of Medicine, \\ Oregon Health Sciences University, \\ Portland, OR 97201, U.S.A. \\ 3 Corresponding author \\ Accepted 17 June 1997
}

Abbreviations: IGF, insulin-like growth factor; IGFBP, IGF binding protein; CTGF, connective tissue growth factor; ECM, extracellular matrix; PPP, platelet-poor plasma; IDDM, insulin-dependent diabetes mellitus; TGF- $\beta$, transforming growth factor $\beta$

\begin{abstract}
The insulin-like growth factor binding protein (IGFBP) family is a critical component of the insulin-like growth factor (IGF) system which regulate the biological actions of the IGFs and may also be capable of IGFindependent actions. To date, seven distinct IGFBPs have been described. Among these IGFBPs, IGFBPs1-6 bind IGFs with high affinity, while only IGFBP-7 binds with low affinity. Recently, we have demonstrated that connective tissue growth factor (CTGF) also binds IGFs with low affinity, suggesting that a family of low-affinity IGFBPs, distinct from the highaffinity members, may exist, and together these constitute an IGFBP superfamily. IGFBPs have various biological roles. IGFBPs act not only as a carrier proteins, but also as a modulators of IGF actions by involving in IGF ligand-receptor interactions through influences on both the bioavailability and distribution of IGFs in the extracellular environment. In addition, some IGFBPs (IGFBPs-1, -3, and -5) appears to have intrinsic activity independent of IGFs. This review will focus on recent studies on the biological roles of IGFBPs in IGF-dependent and IGF-independent modes.
\end{abstract}

Keywords: insulin-like growth factors, insulin-like growth factor binding proteins, connective tissue growth factor, review literature

\section{Introduction}

Insulin-like growth factors (IGFs) are important mitogenic and anabolic polypeptides thought to be involved in normal and malignant cellular proliferation (Daughaday and Rotwein, 1989; Rotwein 1991). IGFs are structurally related to insulin and have both rapid insulin-like effects and slower growth-promoting, anabolic effects. The biological functions of the IGFs are mediated by a family of transmembrane receptors, which includes the insulin, type 1 and type 2 IGF receptors, but primarily through the type 1 IGF receptor (Massague and Czech, 1982). The IGFs and insulin comprise a superfamily of ancient, anabolic peptides, represented across the animal phyla (Murray-Rust et al., 1992). Over the course of evolution, ancestral "insulin-like" gene gave rise to insulin and IGFs, having distinct anabolic roles (Nagamatsu et al., 1991). These facts are supported by the findings that 1) human IGF-I and proinsulin share an overall amino acid sequence homology of $48 \%$ (Rinderknecht and Humbel, 1978); and 2) a gene encoding a polypeptide with a deduced sequence that contains features of both insulin and IGFs was detected in the primitive cephalochordate Branchiostoma californiensis (Chan et al., 1990). However, IGFs differ from insulin in at least two respects: 1) the insulin gene is expressed exclusively in the pancreatic $\beta$-cells (Falkmer, 1985), while the IGFs are expressed in virtually all cell types; and 2) IGFs are bound in biological fluids to the IGF binding proteins (IGFBPs), while insulin reportedly has no affinity for any of the IGFBPs (Rechler, 1993; Rosenfeld et al., 1994).

At the present time, seven distinct IGFBPs have been described (Lee et al., 1988; Binkert et al., 1989; Wood et al., 1989; LaTour et al., 1990; Kiefer et al., 1991a, b; Shimasaki et al., 1991; Oh et al., 1996). They share an overall protein sequence homology of $50 \%$ and contain 12-18 conserved cysteines in the $\mathrm{NH}_{2}$ and $\mathrm{COOH}$-terminal regions (Shimasaki and Ling, 1991; Oh et al., 1996). Among of them, IGFBPs -1-6 bind IGFs with high affinity, while IGFBP-7 has relatively low affinity. In addition, we have recently demonstrated that the protein product of the human connective tissue growth factor (CTGF) cDNA is structurally related to the IGFBPs, and specifically binds IGFs, although with relatively low affinity, thereby constituting another new member of the IGFBP family, IGFBP-8 (Kim et al., 1997). Based upon our observations, we have proposed that IGFBP-7 and CTGF/IGFBP-8 are members of a family of low-affinity IGFBPs, distinct from the high-affinity members, and together these constitute an IGFBP superfamily. Some structural and genetic characteristics of the high-affinity and low-affinity 
Table 1. Structural and genetic characteristics of human IGFBP superfamily.

\begin{tabular}{|c|c|c|c|c|c|c|}
\hline IGFBP & $\begin{array}{c}\text { Molecular } \\
\text { weight }\end{array}$ & $\begin{array}{c}\text { No of } \\
\text { aa }\end{array}$ & $\begin{array}{c}\text { No of } \\
\text { cysteins }\end{array}$ & $\begin{array}{c}N \text {-linked } \\
\text { glycosylation }\end{array}$ & $\begin{array}{c}\text { Chromosomal } \\
\text { localization }\end{array}$ & $\begin{array}{l}\text { mRNA } \\
\text { size (kb) }\end{array}$ \\
\hline \multicolumn{7}{|c|}{ High affinity IGFBPs } \\
\hline IGFBP-1 & 25,271 & 234 & 18 & No & $7 p$ & 1.6 \\
\hline IGFBP-2 & 31,355 & 289 & 18 & No & $2 q$ & 1.5 \\
\hline IGFBP-3 & 28,717 & 264 & 18 & Yes & $7 p$ & 2.4 \\
\hline IGFBP-4 & 25,957 & 237 & 20 & Yes & $17 q$ & 1.7 \\
\hline IGFBP-5 & 28,553 & 252 & 18 & No & $2 q$ & $1.7,6.0$ \\
\hline IGFBP-6 & 22,847 & 216 & 16 & No & 12 & 1.1 \\
\hline \multicolumn{7}{|c|}{ Low affinity IGFBPs } \\
\hline IGFBP-7 & $?$ & 251 & 18 & Yes & $4 q$ & 1.1 \\
\hline IGFBP-8 & $?$ & 349 (pre) & 39 & Yes & $6 q(c-m y b)$ & 2.4 \\
\hline IGFBP-9 & $?$ & 357 (pre) & 41 & $?$ (No) & $8 q(c-m y c)$ & 2.4 \\
\hline IGFBP-10 & $?$ & 379 (pre) & 35 & $?(\mathrm{No})$ & $?$ & 2.4 \\
\hline
\end{tabular}

IGFBPs are shown in Table 1.

The IGFBPs have been proposed to have important functions that are essential to regulate the biological activities of the IGFs and may also be capable of IGFindependent actions. These actions are 1) to act as carrier proteins; 2 ) to prolong the half-lives of the IGFs and regulate their metabolic clearance; 3 ) to provide a means of functional and /or tissue specificity: such specificity is attained not only through different IGFBPs taking on specialized roles, but, importantly, also through differential post-translational modifications that can alter their biological activity; 4 ) to directly modulate interaction of the IGFs with their receptors and thereby indirectly regulate the biological actions of the IGFs; and 5) to directly modulate normal and malignant cell growth in some IGFBPs, independent of IGFs (Andress and Birnbaum, 1992; Jones et al., 1993a; Oh et al., 1993a; Jones and Clemmons, 1995).

In serum, most of the IGFs (> $90 \%$ in adult serum) circulate as a $150-k D a$ ternary complex (IGF-I or IGF-II, IGFBP-3 and a bound acid-labile subunit) (Martin and Baxter, 1986). All three subunits are positively regulated by growth hormone $(\mathrm{GH})$ in vivo, and their levels in the circulation are directly correlated with body growth (Rosenfeld et al., 1994). This high molecular weight ternary complex appears to prevent IGFs and IGFBP-3 from crossing the capillary barrier (Baxter, 1994), as well as increase the half-life of IGF-I in the circulation to 1215 hours (Guler et al., 1989). Meanwhile, the other IGFBPs (IGFBPs-1,-2 and -4) appear to have the ability to cross the capillary barrier, and play an important aspect in the dynamics of the IGF/IGFBP system at the cellular level. The amount of IGFBP-5, -6 and -7 in human serum is relatively low and is unlikely to be of great physiological significance at that level. The relative concentrations of each of the IGFBPs vary among biological fluids; IGFBP1 is the major IGFBP in human amniotic fluid (Drop et al.,
1979), and IGFBP-2 is prominent in cerebrospinal fluid (Rosenfeld et al., 1989) and seminal plasma (Rosenfeld et al., 1990), while IGFBP-3 is the major IGFBP in normal human serum (Martin and Baxter, 1986). In this paper, we will review recent studies on the biological roles of IGFBPs in controlling cellular actions in cultured cell systems and in whole organisms in IGF-dependent and IGF-independent modes.

\section{IGF-dependent actions of the IGFBPs}

Under most conditions, both in vivo and in vitro, the IGFBPs appear to inhibit IGF action, presumably by competing with the IGF receptor for IGF peptides (Zapf et al., 1979). However, under specific conditions, several of the IGFBPs are also apparently capable of potentiating IGF action, perhaps by facilitating IGF delivery to target receptors (Elgin et al., 1987). A source of such discrepancy may come from the effects of the several factors that can influence IGF actions. These are 1) the several specific proteases for IGFBPs, which may cleave the binding proteins into fragments that have either significantly reduced or no affinity for IGFs; 2) posttranslational modifications (e.g. phosphorylation); 3) differential localization of the IGFBPs (e.g. on the cell surface or in the extracellular matrix [ECM]); and 4) the direct cellular effects that are not dependent on the IGFs.

Since the extent of posttranslational modifications can alter IGFBP affinity, such as proteolysis, phosphorylation, and glycosylation, effects of IGFBPs on IGF ligandreceptor interactions should be interpreted with caution. Proteolysis occurs with IGFBPs-2-5. After proteolytic cleavage, their affinity for IGFs is reduced. In the case of IGFBP-3 and -5 , the fragments may retain significant affinity for IGFs and, furthermore, may potentiate IGF actions. Preliminary characterization of these proteases 
has shown that the proteases are calcium-dependent, serine proteases. The exact roles of these proteases in controlling the distribution of IGFs in serum are undetermined. At the same time, the relationship between the activity of the proteases and various pathophysiological conditions should be determined. Serine phosphorylation has been demonstrated for IGFBP-1, -3 , and -5 (Jones et al., 1991). A significant change in affinity for IGF-I after phosphorylation has been proven only for IGFBP1. Glycosylation has been shown to occur for IGFBP-3, $-4,-5$ and -6 , although only O-linked glycosylation is present in IGFBP-5 and -6 . The functional significance of glycosylation has not been determined (Jones and Clemmons, 1995). In addition, IGFBP-1, -3 and -5 specifically bind to molecules on the cell surface. IGFBP1 and IGFBP-2 contain an integrin receptor recognition sequence, Arg-Gly-Asp (RGD sequence) which allows them to specifically associate with the $\alpha 5 \beta 1$ integrin (fibronectin) receptor (Shimasaki and Ling, 1991). IGFBP3 and -5 adhere to different molecules that are present on cell surfaces and in ECM. An increase of binding or adherence of IGFBP-1, -3 and -5 on the cell surface may stimulate mitogenesis, by providing a sustained release of IGF-I to the cells. Nevertheless, IGF-independent actions have been also shown for IGFBP- 1 and -3 and for a fragment of IGFBP-5. This will be discussed later.

\section{IGFBP-1}

IGFBP-1 exists as a non-glycosylated protein of $30 \mathrm{kDa}$ molecular weight (Shimasaki and Ling, 1991), and it is strongly expressed in liver and kidney.

Most studies in cell culture systems under serum-free conditions indicate that the addition of purified IGFBP-1 results in inhibited cell growth and/or inhibited differentiated cell function. These inhibitory effects have been attributed to IGFBP-1 interference with IGF ligand-receptor interactions. Definitive inhibition generally occurs when the IGFBP-1 is added in molar excess (usually at least 4:1). Busby et al. (1988) showed that IGFBP-1 purified from amniotic fluid inhibited IGF-I stimulated $\left[{ }^{3} \mathrm{H}\right]$ thymidine incorporation into porcine aortic smooth muscle cells and fibroblasts. Other cell types that were shown to be inhibited by IGFBP-1 include JEG-3 choriocarcinoma cells, FRTL5 thyroid cells, chick embryo pelvic leaflets, chick embryo fibroblasts, and JMGE-3 osteosarcoma cells (Jones and Clemmons, 1995). Angervo et al. (1991) showed that IGFBP-1 also inhibited DNA synthesis in cultured human granulosa-luteal cells and postulated that IGFBP-1 may play an important role in lutealization since these cells undergo mitotic arrest during that time, with IGFBP-1 making them refractory to further growth stimulation by IGF-I. IGFBP-1 also inhibits glucose incorporation into BALB/c 3T3-fiboblasts (Okajima et al., 1993). This is consistent with a possible role of IGFBP-1 in glucose counterregulation; acute administration of IGFBP-1 to rats can reduce the glucose-lowering effect of IGF-I transiently (Lewitt et al., 1991).

In contrast, IGFBP-1 can potentiate IGF-I action if a low concentration of platelet-poor plasma (PPP) is included in the culture medium. Elgin et al. (1987) have shown that IGFBP-1 potentiates the effect of IGF-I on DNA synthesis in porcine aortic smooth muscle cells in culture medium with a low concentration of PPP. The factor in PPP has been shown to be not dialyzable, heatand acid-stable, and cannot be replaced by the addition of other growth factors (Clemmons and Gardner, 1990). However, IGFBP-1 can stimulate cell growth in some cell systems (MDA-231 breast carcinoma cell) without added PPP (Camacho-Hubner et al., 1991). Koistinen et al. (1990) reported that IGFBP-1 can simul-taneously inhibit binding of IGF-I to cell surfaces and stimulate their mitogenesis, suggesting that IGFBP-1 may be potentiative, by providing a sustained release of IGF-I to receptors. Such potentiation by IGFBP-1 may require its cell association. Busby et al. (1988) reported that there are two isoforms of IGFBP-1 in amniotic fluids that differed in their ability to bind to cell surfaces and to form disulfidelinked multimers. The form that associated with cell surfaces and polymerized, resulted in potentiation of IGF-I action in the presence of PPP, while the other isoform that showed no capability to be associated with cell surfaces and polymerized inhibited IGF action. This finding supports the importance of cell surface association and/or multimer formation of IGFBP-1 for potentiation of IGF action to occur. IGF-mediated actions can be potentiated by the binding of IGFBP- 1 to the $\alpha 5 \beta 1$ integrin (fibronectin) of which is mediated through an integrin receptor recognition sequence (RGD). In this circumstance, integrin-bound IGFBP-1 could act as a reservoir for IGF, which could provide a high concentration of IGF to stimulate the IGF-I receptor. Phosphorylated forms of IGFBP-1 have been observed in human amniotic fluid and fetal serum (Jones et al., 1991) as well as human decidual cultures (Frost and Tseng, 1991), CHO cells transfected with an IGFBP-1 construct and nontransfected Hep G2 cells (Jones et al., 1991). It has been known that the isoforms that inhibit IGF action are phosphorylated while the isoform that stimulates IGF action is nonphosphorylated (Busby et al., 1988). The observations of Westwood et al. (1994) further support this concept. They recently demonstrated that IGFBP-1 in normal plasma exists as a single, highly phosphorylated species (high affinity), while in pregnant maternal plasma and in amniotic fluid, IGFBP-1 is either nonphosphorylated or exhibited reduced phosphorylation (lower affinity), suggesting that the reduced-affinity IGFBP-1 in pregnancy tissues may promote conceptus growth by increasing IGF bioavailability to its receptors.

The roles of IGFBP-1 and its regulation are associated with different physiological or pathophysiological processes. IGFBP-1 expression is strongly and acutely stimulated under catabolic conditions. Both insulindependent diabetes mellitus (IDDM) and the fasting state 
result in dramatically increased IGFBP-1 mRNA in liver, kidney and other tissues (Lee et al., 1993). IGFBP-1 expression appears to be regulated by insulin (which is inhibitory) and glucocorticoids (which are stimulatory) associated with catabolic processes. Administration of IGFBP-1 to rats in vivo can induce an elevation of blood glucose (Lewitt et al., 1991). IGFBP-1 is also involved in a variety of reproductive functions, including endometrial cycling, oocyte maturation, and gestational development (Kelley et al., 1996). The concentration of IGFBP-1 in amniotic fluid and fetal serum $(3000 \mathrm{ng} / \mathrm{ml}$ by the second trimester of gestation) is higher than that in maternal serum (about $25 \mathrm{ng} / \mathrm{ml}$ ) (Nonoshita et al., 1994). The elevated levels of high affinity IGFBP-1 in the fetal compartment, combined with reduced and/or proteolyzed (low affinity) IGFBP-3 in the maternal circulation, provide for a gradient down which IGFs can move toward the amniotic fluid and fetal circulation. In diabetic kidney, renal IGFBP-1 mRNA and protein expression are significantly increased and result in an aberrant and activated growth response within the tissue (Landau et al., 1995), suggesting that IGFBP-1 is a strong candidate both as a local sequesterer of IGFs as well as a possible cellular mediator of the aberrant growth activity.

\section{IGFBP-2}

The actions of IGFBP-2 on IGF-mediated functions have been reported to be both inhibitory and stimulatory, although it has received less intensive analysis than IGFBP-1 or -3. IGFBP-2 has been shown to have an RGD sequence and is not glycosylated or phosphorylated.

Purified IGFBP-2 has been shown to inhibit [ $\left.{ }^{3} \mathrm{H}\right]$ thymidine incorporation into chick embryo fibroblasts and rat astroglial cells (Knauer and Smith, 1980), and inhibit the activity of IGF-II to stimulate DNA synthesis in human lung carcinoma cells (Reeve et al., 1993).

IGFBP-2 has been reported to potentiate IGF action weakly. Addition of IGFBP-2 to microvascular endothelial cells in serum-free medium slightly stimulates cellular glucose transport and aminoisobutyric acid uptake (Bar et al., 1989). Bourner et al. (1992) have also reported that bovine IGFBP-2 can potentiate IGF-I action in porcine aortic smooth muscle cells in the presence of a low concentration of PPP.

The physiological actions of IGFBP-2 are also not well characterized. IGFBP-2 may be involved in fetal development, particularly in the central nervous system by participating in pituitary development and in the transport of IGF-II to the cerebrospinal fluid (Wood et al., 1992). In adults, the IGFBP-2 gene is strongly expressed in the central nervous system and is the major IGFBP in cerebrospinal fluid (Lamson et al., 1989). The regulation of IGFBP-2 is also associated with metabolism and reproduction. Prolonged fasting and IDDM in rats result in significantly increased IGFBP-2 in liver, although kidney, brain and other tissues show no such changes (Thissen et al., 1994). IGFBP-2 is also expressed in a number of reproductive tissues and is the most abundant IGFBP in seminal plasma (Rosenfeld et al., 1990). Cohen et al. (1994a) reported that IGFBP-2 expression in prostatic stromal cells from patients with benign prostatic hyperplasia is significantly reduced and suggested that activated growth in benign prostatic hyperplasia is partly supported by reduced inhibitory IGFBP-2. In lung carcinoma cell lines, IGFBP-2 expression is also reduced, and that works in a same manner.

\section{IGFBP-3}

IGFBP-3 has been reported to modulate the action of IGFs both positively and negatively, and may also be capable of IGF-independent inhibitory actions on cell growth. Although IGFBP-3 is expressed as a single protein sequence, there are various forms by posttranslational modifications. These include the various degree of glycosylation during cellular synthesis of IGFBP-3, and proteolytic cleavage in the extracellular environment. Recombinant IGFBP-3 from E.coli (nonglycosylated form) (Sommer et al., 1992) or chemically deglycosylated IGFBP-3 (Martin and Baxter, 1992) have a molecular weight of around $29 \mathrm{kDa}$. By comparison, IGFBP-3 is heavily glycosylated on two (human) or three (rat) $\mathrm{N}$ linked and two potential O-linked glycosylation sites and is usually produced as a doublet of 43 and $45 \mathrm{kDa}$ (Baxter, 1994). There are no significant differences in affinity for IGF-I between nonglycosylated and glycosylated IGFBP3. Serine phosphorylation of IGFBP-3 has also been reported, although site-directed mutagenesis of two of the phosphorylated serines did not affect IGF binding activity (Hoeck and Mukku, 1994).

IGFBP-3 is a well-documented inhibitor of cellular proliferation and differentiation. Excess of purified IGFBP3 , when added together with IGF-I to human skin fibroblast, could inhibit IGF-I stimulated DNA synthesis (DeMellow and Baxter, 1988). IGFBP-3 has also been shown to inhibit glucose incorporation in BALB/c 3T3 cells (Okajima et al., 1993), IGF-I stimulated cAMP generation and DNA synthesis in rat granulosa cells (Bicsak et al., 1990), and IGF-I stimulated DNA and collagen synthesis in rat osteoblasts (Schmid et al., 1991). Preincubation with IGFBP-3 alone also resulted in inhibition of subsequent effects of IGF-I or IGF-II. The mechanism by which IGFBP-3 inhibits IGF action is related to its ability to inhibit IGF binding to IGF-I receptors.

In contrast, Cornell et al. (1986) have demonstrated that IGFBP-3 could potentiate the effects of IGF on glucose incorporation, which is not consistent with other observations (DeMellow and Baxter, 1988). These conflicting results can be attributed to the difference in treatment with IGFBP-3. Preincubation of human fibroblasts with IGFBP-3 followed by its removal resulted in substantial potentiation of the effect of IGF-I on DNA synthesis, whereas coincubation resulted in inhibition. 
Conover et al. (1990) showed that bovine IGFBP-3 affected the aminoisobutyric acid uptake response to IGF$I$ in fibroblast cultures in the same manner. Potentiation of IGF action by IGFBP-3 appears to require its cellsurface association. Since IGFBP-3 in solution has a higher affinity for IGFs than does the type-1 IGF receptor, IGFBP-3 in solution works as a strong competitive inhibitor of IGFs. However, cell association of IGFBP-3 results in a 10-fold-reduced affinity for IGF-I compared with IGFBP3 in solution (McCusker et al., 1990; Conover, 1991), and therefore it is capable of modulating IGF receptor interactions such that IGFs are more available for receptor binding. Conover (1991) reported that glycosylation of IGFBP-3 was not required for binding to cell surfaces or potentiating IGF-I action. Conover (1991) furthermore suggested that the IGFBP-3 that adhered to the cell surface was processed to a lower molecular weight forms, and that these had a lower affinity for IGF-I. Proteolysis of IGFBP-3 may thus be important for the potentiative action of IGFBP-3. Schmid et al. (1991) have reported that truncated IGFBP-3 (28-30 kDa IGFBP-3 fragment) potentiated IGF-I action, whereas intact IGFBP-3 inhibited IGF-I action on thymidine incorporation into DNA in a rat osteoblast cell line. In prostate epithelial cells, proteolysis of IGFBP-3 resulted in a loss of inhibition by IGFBP-3 on IGF-I-mediated cell growth (Cohen et al., 1994b). These data indicate that cell association and/or local proteolysis of IGFBP-3 may modulate its cellular activity and cells can regulate the bioavailability of IGFs through the use of proteases.

Serum proteolysis of IGFBP-3 is likely to exist to some degree under different physiological or pathophysiological conditions to regulate the availability of IGFs. The proteolysis of IGFBP-3 has been known firstly from the studies on serum IGFBP levels during pregnancy (Fielder et al., 1990; Giudice et al., 1990; Hossenlopp et al., 1990). The predominant IGFBP-3 in pregnancy serum is a proteolyzed fragment of 28-30 kDa (Fielder et al., 1990). This fragment binds IGF-I with reduced affinity, but can still exist in the ternary complex with acid-labile subunit and IGF (Bang et al., 1994a). The source of the pregnancy IGFBP-3 protease appears to be the decidua (Davenport et al., 1992). Bang et al. (1994b) recently reported that in serum from patients with NIDDM, an IGFBP-3 protease produces a $28-30 \mathrm{kDa}$ IGFBP-3 fragment similar to that produced by the pregnancy IGFBP-3 protease. Recently, other proteases were found in prostate cancer (identified as prostate specific antigen) (Cohen et al., 1994b), and in cultured prostatic cells (identified as cathepsin D) (Conover et al., 1994).

More recently, Buckbinder et al. (1995) demonstrated that induction of IGFBP-3 gene expression by wild-type, but not mutant, p53 is associated with enhanced secretion of an active form of IGFBP-3 capable of inhibiting mitogenic signalling by IGF-I. Their results indicate that IGFBP-3 may link p53 to potential novel autocrine/ paracrine signalling pathways and to processes regulated by or dependent on IGFs, such as cellular growth, transformation and survival.

\section{IGFBP-4}

IGFBP-4 appears to inhibit IGF actions under most experimental conditions, and to date there have been no reports to indicate a potentiative action of IGFBP-4 at the cellular level. IGFBP-4 contains one $N$-linked glycosylation site, and exists in biological fluids as a doublet: a 24-kDa nonglycosylated form and a $28-\mathrm{kDa}$ glycosylated form. The physiological significance of glycosylated IGFBP-4 has not been determined. IGFBP4 does not seem to adhere to cell surfaces. Proteolysis of IGFBP-4 results in proteolytic fragments (14 and 18 $\mathrm{kDa}$ ) that have very low or no IGF binding capacity.

IGFBP-4 was initially isolated on the basis of its inhibition of IGF-stimulated cell proliferation. Mohan et al. (1989) isolated this binding protein from an osteosarcoma cell line, and showed that it was a potent inhibitor of IGF action. Ui et al. (1989) isolated IGFBP-4 on the basis of its ability to inhibit steroidogenesis in rat granulosa cells. Likewise, Culouscou et al. (1991) purified IGFBP-4 on the basis of its ability to inhibit the growth of a colon carcinoma cell line. The mechanism by which IGFBP-4 inhibits IGF-mediated cell functions is by the binding of IGFBP-4 to IGFs, thereby preventing the interaction of the IGFs with their receptors (Kiefer et al., 1992). This inhibitory effect of IGFBP-4 can be relieved by proteolysis, and this provides for a cellular mechanism to increase local IGF concentrations. IGFBP-4 proteases were found in a variety of cell types, including fibroblasts (Conover et al, 1993), smooth muscle cells (Cohik et al., 1993), neuroblastoma (Cheung et al., 1994), bone-derived cells (Durham et al., 1994), and prostate (Lee et al., 1994). Since IGFBP-4 proteases are specific, they do not proteolyze the other IGFBPs, and these proteases are activated in the presence of IGF-I or IGF-II (Neely and Rosenfeld, 1992). Activation of proteolysis by IGF can occur under cell-free conditions and appears to be the result of IGF binding to IGFBP-4. Conover et al. (1993) reported that IGF-II may be more effective that IGF-I in activating IGFBP-4 proteolysis, and suggested a mechanism wherein low concentrations of IGF-II could increase local availability of IGF-I. Glucocorticoids (Okazaki et al., 1994), para-thyroid hormone (LaTour et al., 1990), growth hormone (Schmid et al., 1989), and 1,25-dihydroxyvitamin D3 (Scharla et al., 1991) have also been known to influence IGFBP-4 and/or its susceptibility to proteolysis in bone cells.

The physiological regulation of IGFBP-4 and its protease is poorly understood. Rodgers et al. (1995) reported that circulating IGFBP-4 levels are significantly reduced in uncontrolled IDDM. He also proposed that in vivo IGFBP-4 could be considered growth promoting, by showing that tibial epiphyseal plate width was positively 
correlated with IGFBP-4 concentrations in diabetic rats.

\section{IGFBP-5}

IGFBP-5 has a molecular weight of $29 \mathrm{kDa}$, has no $N$ linked glycosylation sites, but exhibits $O$-linked glycosylation (Conover and Kiefer, 1993). Serine phosphorylation of IGFBP-5 has also been reported (Jones et al., 1991).

IGFBP-5 has been shown to inhibit IGF-I-stimulated DNA and glycogen synthesis in human osteosarcoma cells when a molar excess of IGFBP-5 was used (Kiefer et al., 1992). Ling et al. (1993) has also reported that inhibition of steroidogenesis in granulosa cells stimulated with IGF-I, suggesting that IGFBP-5 had an inhibitory function.

IGFBP-5 has been shown to adhere to fibroblast ECM. When IGFBP-5 was incubated with ECM, it potentiated the effect of IGF-I on cell growth by approximately $100 \%$ (Jones et al., 1993b). IGFBP-5 added to the medium was cleaved to a $21-\mathrm{kDa}$ fragment, while IGFBP-5, either added exogeneously to the ECM or synthesized by fibroblasts and bound to ECM was present only in an intact form, suggesting that proteolysis of IGFBP-5 could be prevented by binding to ECM. Proteolyzed IGFBP-5 fragments did not potentiate the action of IGF-I. Since the ECM-associated IGFBP-5 has lower affinity for IGFI by approximately 7-fold, ECM-associated IGF-I could act as a reservior for release of IGF for cell surface receptors. The binding of IGFBP-5 to ECM results in the potentiation of IGF-mediated cell functions by lowering of IGFBP-5 affinity for IGF and protecting it from proteolysis. Cell surface association of IGFBP-5 may also mediate its ability to potentiate IGF actions. Jones et al. (1993b) suggested this as a mechanism whereby cell-associated IGFBP-5 serves as a stable IGF-binding site and, with its reduced affinity, promotes IGF ligand-receptor interaction. As described earlier, when IGFBP-4 binds to IGF, its proteolysis is stimulated, which results in reduced affinity for IGF. However, IGFBP-5 is protected from proteolysis when bound to IGF (Conover and Kiefer, 1993). Proteolysis of recombinant IGFBP-5 $(29 \mathrm{kDa})$ results in proteolytic fragments of 20,17 and $16 \mathrm{kDa}$, and similar IGFBP-5immunoreactive fragments have been observed in human serum (Kiefer et al., 1992). Andress and Bimbaum (1992) reported that a 23-kDa IGFBP-5 fragment (truncated at the C-terminus) purified from U-2 cells had a highly reduced affinity for IGFs and potentiated IGF-I-stimulated mitogenesis in both $\mathrm{U}-2$ cells and in normal mouse osteoblasts. A serine protease that cleaves IGFBP-5 was found in human fibroblast conditioned medium by Nam et al. (1994). Active fractions obtained from a heparin-Sepharose column exhibited proteolytic activity specific for IGFBP-5 and resulted in IGFBP-5 fragments of 22,20 and $17 \mathrm{kDa}$. It was found that heparin inhibited IGFBP-5 proteolysis, suggesting that the basic region within IGFBP-5 that is important for its ECM association may also be the site at which IGFBP-5 proteases cleave
(Bar et al., 1994). Similar fragments resulting from proteolysis of IGFBP-5 have been reported in follicle stimulating hormone (FSH)-stimulated rat granulosa cells (Fielder et al., 1993) and in seminal plasma (Lee et al., 1994). Bautista et al. (1991) have also demonstrated that addition of equimolar concentrations of IGF-II and IGFBP-5 in mouse MC3T3-E1 osteoblast culture resulted in potentiation of IGF-II action.

IGFBP-5 is the predominant IGFBP in bone extracts, and is believed to function in the bone matrix to fix IGFs in the tissue and to promote IGF ligand-receptor interaction. In addition, IGFBP-5 appears to play a significant role in ovarian function. IGFBP-5 and IGFBP-4 are predominantly expressed in the granulosa cells in rat. In healthy follicles, IGFBP-5 and IGFBP-4 expression is inhibited, while the opposite is true in degenerative, atretic follicles, suggesting that the intrafollicular levels of IGFBP-5 and IGFBP-4 may be important determinants of follicular selection (Adashi, 1994). IGFBP-5 is also associated with growth inhibition in the kidney. In the kidney, IGFBP-5 is the most abundantly expressed IGFBP, and its expression in vivo appears to be inversely related to renal growth activity (Shimasaki and Ling, 1991). Landau et al. (1995) observed that renal expression of IGFBP-5, as well as of IGFBP-3, was significantly reduced early in the onset of IDDM, suggesting that, in addition to increased IGFBP-1, which might sequester IGFs locally, diabetic renal disease might also be characterized by a relief from inhibition by IGFBP-5 and IGFBP-3.

\section{IGFBP-6}

Since IGFBP-6 is rather recently isolated and cloned, studies are limited. IGFBP-6 exists as a $30-k D a$ protein and seems to have only O-linked glycosylation, although it contains one $N$-linked glycosylation site (Bach et al., 1993). Deglycosylated or recombinant (nonglycosylated) IGFBP-6 is approximately 24-25 kDa (Kiefer et al., 1992). Although IGFBP-6 contains a heparin-binding consensus domain, recombinant IGFBP-6 does not specifically bind endothelial cell monolayers and has a low affinity for heparin (Bar et al., 1994). No IGFBP-6 protease has yet been identified. IGFBP- 6 has been shown to have a markedly lower affinity for IGF-I than for IGF-II (Kiefer et al., 1992). IGFBP-6 is detected in cerebrospinal fluid, serum, and in other fluids (Baxter and Saunders, 1992). Serum levels of IGFBP-6, although low, are found to be lower in females and are further reduced during pregnancy.

IGFBP-6 appears to have an antigonadotropic activity in the rat ovary (Rohan et al., 1993). FSH treatment significantly reduces tissue IGFBP-6 expression in rats, suggesting that IGFBP-6 may antagonize follicular development. However, recombinant human IGFBP-6 had no inhibitory effect on FSH-stimulated steroidogenesis in rat granulosa cells in culture. Zhou et al. (1994) 
have recently reported that IGFBP-6 expression is increased during the secretory phase of the menstrual cycle, suggesting that IGFBP-6 may be associated with endometrial cycling.

\section{IGF-independent actions of the IGFBPs}

\section{IGFBP-1}

IGFBP-1 (and IGFBP-2) contains an integrin receptor recognition sequence, Arg-Gly-Asp (RGD sequence) which allows it to specifically bind the a5b1 integrin (fibronectin) receptor (Shimasaki and Ling, 1991). Jones et al. (1993a) have demonstrated that IGFBP-1 binds specifically to the a5b1 integrin receptor and showed the functional significance of this interaction in cultured Chinese hamster ovary $(\mathrm{CHO})$ cells. The expression of recombinant IGFBP-1 by $\mathrm{CHO}$ cells or the addition of IGFBP-1 to the culture medium stimulated cell migration. In contrast, mutation of the RGD sequence to Trp-GlyAsp (WGD) in IGFBP-1 by in vitro mutagenesis prevented it from binding to the integrin receptor or stimulating cell migration. The addition of a synthetic RGD-containing peptide to the culture medium with IGFBP-1 resulted in blockage of the effect of IGFBP-1 on cell migration. The effect on migration of IGFBP-1 in this system was independent of IGF-I, since 1) the WGD mutation did not affect binding affinity for IGF-I, 2) addition of IGF-I to the medium had no effect on cell migration, and 3) no endogenous IGF-I or IGF-II or their mRNAs could be detected.

\section{IGFBP-3}

Several recent lines of evidence have indicated that IGFBP-3 by itself has intrinsic inhibitory effects on cells, independent of its interaction with IGF. Villaudy et al. (1991) showed that IGFBP-3 inhibited DNA synthesis in mouse embryo fibroblasts that had been stimulated by basic fibroblast growth factor (FGF), even in the presence of $1000 \mathrm{ng} / \mathrm{ml}$ insulin. Since the IGF-I receptors were occupied by insulin at high concentrations, this finding suggested that IGF receptor occupancy was not related to IGFBP-3 action. Imbenotte et al. (1992) demonstrated that IGFBP-3 also inhibited chick embryo fibroblast replication stimulated by transforming growth factor $\beta$ (TGF- $\beta$ ). Similarly, IGFBP-3 was found to be more effective than IGF-I-immunoneutralization in inhibiting serum-stimulated DNA synthesis (Liu et al, 1992). Cohen et al. (1993) reported that, in BALB/c3T3 fibroblasts, overexpression of a transfected human IGFBP-3 cDNA strongly inhibits cell proliferation, with or without added IGF. Oh et al. (1993a) have demonstrated that IGFBP-3 binds on the cell surface and can inhibit Hs578T human breast cancer cell monolayer growth by itself. They showed that the inhibitory effect of IGFBP-3 was specific and
IGF-independent by demonstrating: 1) dose-dependent inhibition on cell growth and on DNA synthesis by IGFBP3 , but not by IGFBP-1;2) absence of stimulatory effects on monolayer Hs578T cell growth by either IGFs or IGF analogs; and 3) significant diminution of the IGFBP-3 inhibitory effects by coincubation with IGFs, but not with IGF analogs with decreased affinity for IGFBPs. Subsequently, Oh et al.(1993b) have demonstrated cell surface association proteins of 50,26 and $20 \mathrm{kDa}$ that are specific for IGFBP-3, by affinity cross-linking and immunoprecipitation. IGFBP-3-mediated inhibition of cell growth was cation-dependent and blocked by IGF-I and IGF-II, but not by IGF analogs with decreased affinity for IGFBPs, suggesting that these cell surface proteins mediate the direct inhibitory effects of IGFBP-3. The biochemical nature of these proteins has not been determined.

The role of IGFBP-3 as a mediator of cell growth inhibition may be a common feature in the control of cell regulation by other growth factors (Kelley et al., 1996). TGF- $\beta$ is a potent growth inhibitor in human breast cancer cells in vitro and appears to regulate IGFBP-3 production. Oh et al. (1995) have recently demonstrated, using Hs578T cells that TGF- $\beta$ stimulates IGFBP-3 gene expression, and treatment with an IGFBP-3 antisense oligodeoxynucleotide selectively inhibits TGF- $\beta$-induced IGFBP-3 synthesis and cell growth inhibition. Gucev et al. (1995) further showed that retinoic acid, also a potent growth inhibitor in breast cancer cells, inhibits cell growth through a similar modulation of IGFBP-3 expression. These data suggest that IGFBP-3, through intrinsic activity, is an important cellular growth regulator and may also be an important mediator for other cellular growth factors (Kelley et al., 1996).

\section{IGFBP-5}

The functional significance of IGFBP-5 proteolysis may be found in studies by Andress and Birnbaum (1992) using a 23-kDa IGFBP-5 fragment purified from U-2 cells. They reported that a $23-k D a$ IGFBP-5 fragment stimulated mitogenesis in an apparent IGF-independent manner, since simultaneous addition of excess IGFBP3 sufficient to sequester local IGFs did not interfere with the stimulation. Furthermore, they showed that the osteoblast-derived IGFBP-5 stimulated mitogenesis in the absence of exogenous or endogenous IGF, and the binding protein could associate with the osteoblast surface, an effect which did not require IGF or an interaction with the IGF receptors.

\section{New concepts of IGFBPs}

\section{IGFBP-7}

Much less is known about newly identified family of IGFBP. The IGFBP-7 cDNA clones have been isolated 


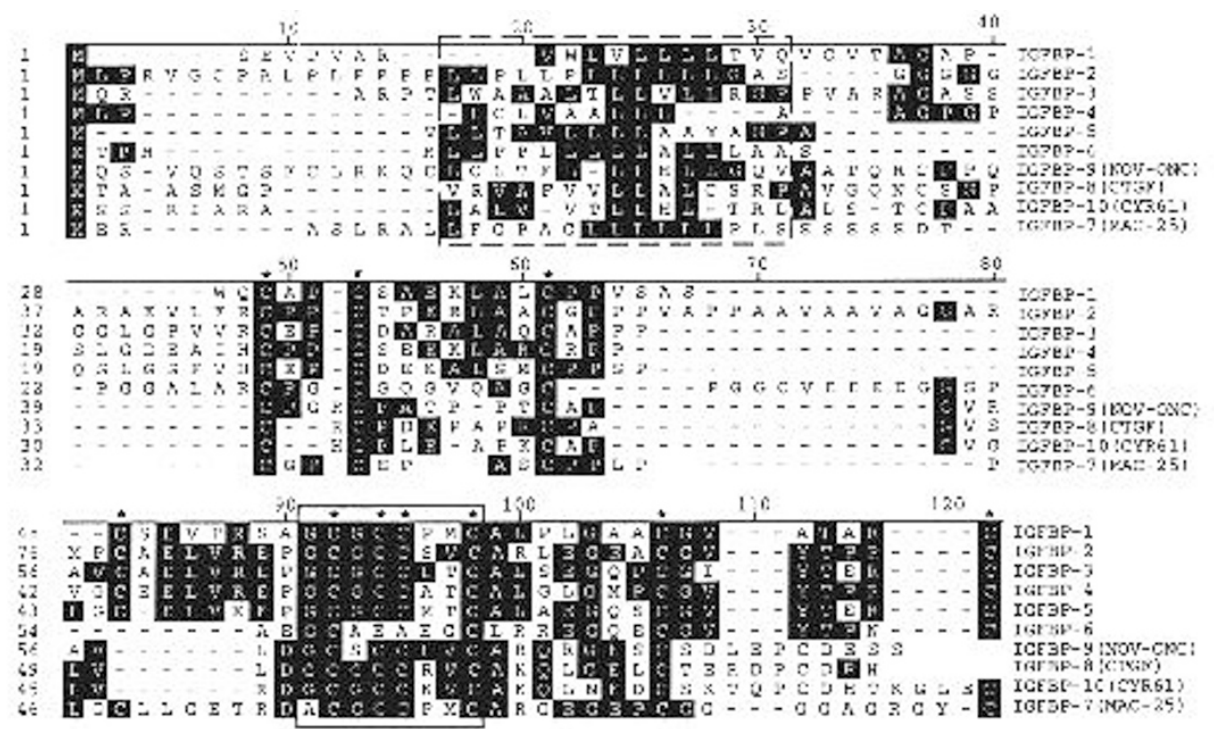

Figure 1.Comparison of $\mathrm{NH}_{2}$-terminal amino acid sequences of IGFBP superfamily. Sequences of IGFBPs-17, CTGF, nov-oncogene, and cyr61 were aligned using the DNAstar MegAlign program. Consensus signal sequences are boxed by a dotted line. The characteristic IGFBP motif (GCGCCXXC) is boxed by a solid line. Conserved cysteine residues in the family are marked with asterisk. We have named mac25 IGFBP-7 and named CTGF IGFBP-8. We have tentatively named the protein products of the nov and cyr61 genes, IGFBP-9 and IGFBP-10, respectively.

from human leptomeningioma cells (Murphy et al., 1993) and mammary epithelial cells (Swisshelm et al., 1995). IGFBP-7 exists as a major 27-kDa protein and a minor higher molecular weight protein of $54 \mathrm{kDa}$ (presumably dimers of the IGFBP-7 protein) and appears to have one $N$-linked glycosylation site; deglycosylated IGFBP-7 is around $25 \mathrm{kDa}$ (Oh et al., 1996). Uniquely among the IGFBPs, IGFBP-7 has a markedly reduced affinity for IGFs; Compared with IGFBP-3, the affinity of IGFBP-7 for IGFs appears to be approximately 5-25-fold lower (Oh et al., 1996). Although the concentration of IGFBP-7 in serum is very low, IGFBP-7 can be detected in various body fluids including in normal human urine, cerebrospinal fluid and amniotic fluid (Wilson et al., 1997).

Physiological significance of IGFBP-7 has not been determined. Swisshelm et al. (1995) have reported that expression of mac25/IGFBP-7 mRNA was elevated in senescent human mammary epithelial cells, while apparently downregulated in mammary carcinoma cell lines. Furthermore, mac25/IGFBP-7 mRNA is up-regulated in normal, growing mammary epithelial cells by alltrans-retinoic acid (RA), suggesting that IGFBP-7 may be a downstream effector of the RA-induced senescence pathway. Taken together with the result showing reduced IGFBP-7 mRNA levels in several cancers such as breast, prostate, colon and lung (Oh et al., 1996), IGFBP-7 may function not only as an IGF binding protein, but also as a direct growth-suppressing factor, with an IGF-independent action similar to that of IGFBP-3. Recently, Oh et al. (1997) have demonstrated that IGFBP-7 is a growth-suppressing factor in breast cancer and it's IGF-independent action and role in mediating TGF- $\beta$-induced growth inhibition may involve interaction with DNA, RNA or nuclear proteins.

\section{Potential candidates of new IGFBPs}

A closely related family of genes encoding CTGF (Bradham et al., 1991), the nov oncogene (Martinerie et al., 1992), and cyr61 (O'Brien et al., 1990) has been identified; the predicted proteins are products of "immediate-early genes" expressed after induction by serum, growth factors or certain oncogenes. Sequence comparison between any member of this new family and IGFBPs shows similarities between $30-38 \%$. Moreover, these proteins also contain the conserved "GFBP motif" (GCGCCXXC) in their aminoterminus and as many as 17 of the 18 cysteines conserved in IGFBPs-1-6 (Figure 1), suggesting that the CTGF/novoncogene/cyr61 family shares significant structural homology with IGFBPs (Bork, 1993) and may potentially bind IGFs. Kim et al. (1997) have demonstrated that

\section{IGRBP Superfamily}

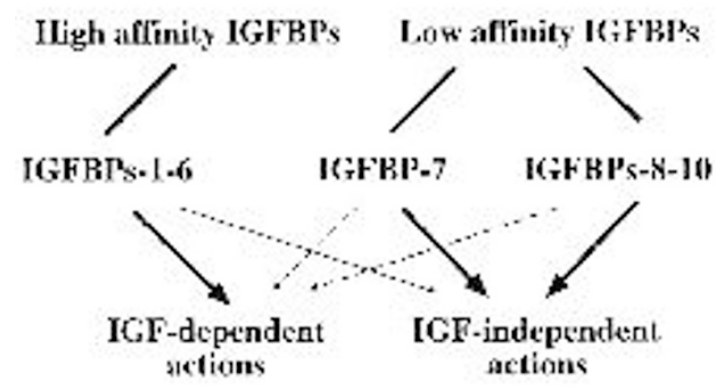

Figure 2. The IGFBP superfamily composed of high-affinity IGFBPs and low-affinity IGFBPs. The thick and thin solid lines represent primary and secondary major actions of the IGFBPs. The dashed lines represent potential actions that have not been demonstrated experimentally. 
CTGF specifically binds IGFs, with relatively low affinity, suggesting that CTGF meets criteria that define it as a new member of the IGFBP family, IGFBP-8. They have further proposed that the six high-affinity IGFBPs and the four potential low-affinity IGFBPs constitute a superfamily of proteins that regulate cell growth through both IGFdependent and IGF-independent actions (Figure 2).

\section{References}

Adashi, E. Y. (1994) Regulation of intrafollicular IGFBPs, possible relevance to ovarian follicular selection. In The Insulin-like Growth Factors and Their Regulatory Proteins (Baxter, R. C., Gluckman, P. D. and Rosenfeld, R. G., eds.), pp. 341-350, Elsevier, Amsterdam

Andress, D. L. and Birnbaum, R. S. (1992) Human osteoblast-derived insulin-like growth factor (IGF) binding protein-5 stimulates osteoblast mitogenesis and potentiates IGF action. J. Biol. Chem. 267: 22467-22472

Angervo, M., Koistinen, R., Suikkari, A. M. and Seppala M. (1991) Insulin like growth factor binding protein-1 inhibits DNA amplication induced by insulin-like growth factor I in human granulosa-luteal cells. Hum. Reprod. 6: 770-773

Bach, L. A., Thotakura, N. R. and Rechler, M. M. (1993) Human insulin-like growth factor binding protein 6 is 0-glycosylated. Growth Regul. 3: 59-62

Bang, P., Brismar, K. and Rosenfeld, R. G. (1994b) Increased proteoly-sis of insulin-like growth factor-binding protein-3 (IGFBP-3) in noninsulin-dependent diabetes mellitus serum, with elevation of a 29-kilodalton ( $\mathrm{KDa}$ ) glycosylated IGFBP-3 fragment contained in the approximately $130-$ to $150-k D a$ ternary complex. J. Clin. Endocrinol. Metab. 78 : 1119-1127

Bang, P., Stangenberg, M., Westgren, M. and Rosenfeld, R. G. (1994a) Decreased ternary complex formation and predominance of a $29 \mathrm{kDa}$ IGFBP-3 fragment in human fetal serum. Growth Regul. 4: 68-76

Bar, R. S., Boes, M., Booth, B. A., Drake, B. L., Moser, D. R. and Erondu, N. E. (1994) Vascular endothelium, IGFs and IGF biding proteins. In The Insulin-like Growth Factors and Their Regulatory Proteins (Baxter, R. C., Gluckman, P. D. and Rosenfeld, R. G., eds.), pp. 237-244, Elsevier, Amsterdam

Bar, R. S., Booth, B. A., Boes, M. and Drake, B. L. (1989) Insulin-like growth factor binding proteins from cultured endothelial cells: purification, characterization, and intrinsic biologic activities. Endocrinology 125: 1910-1920

Bautista, C. M., Baylink, D. J. and Mohan, S. (1991) Isolation of novel insulin-like growth factor (IGF) binding protein from human bone, a potential candidate for fixing IGF-II in human bone. Biochem. Biophys. Res. Commun. 176: 756-763

Baxter, R. C. (1994) Insulin-like growth factor binding proteins in the human circulation, a review. Horm. Res. 42: 140-144

Baxter, R. C. and Saunders, H. (1992) Radioimmunoassay of insulin-like growth factorbinding protein-6 in human serum and other body fluids. J. Endocrinol. 134: 133-139

Bicsak, T. A., Shimonaka, M., Malkowski, M. and Ling, N. (1990) Insulin-like growth factor-binding protein (IGF-BP) inhibition of granulosa cell function: effect of cyclic adenosine 3', 5'-monophosphate, deoxyribonu-cleic acid synthesis, and comparison with the effect of an IGF-I antibody. Endocrinology 126: 2184-2189

Binkert, C., Landwehr, J., Mary, J.-L., Schwander, J. and Heinrich, G. (1989) Cloning, sequence analysis and expression of a cDNA encoding a novel insulin-like growth factor binding protein (IGFBP-2). EMBO J. 8: 2497-2502

Bork, P. (1993) The modular architecture of a new family of growth regulators related to connective tissue growth factor. FEBS Lett. 327: 125-130

Bourner, M. J., Busby, W. H., Seigel, N. R., Krivi, G. G., McCusker, R. H. and Clemmons, D. R. (1992) Cloning and sequence determination of bovine insulin-like growth factor binding protein-2 (IGFBP-2): comparison of its structural and functional properties with IGFBP-1. J. Cell. Biochem. 48: 215-226

Bradham, D. M., Igarashi, A., Potter, R. L. and Grotendorst, G. R. (1991) Connective tissue growth factor: a cysteine-rich mitogen secreted by human vascular endothelial cells is related to the SRC-induced immediate early gene product cef-10. J. Cell Biol. 114: $1285-1294$

Buckbinder, L., Talbott, R., Velasco-Miguel, S., Takenaka, I., Faha, B., Seizinger, B. R. and Kley, N. (1995) Induction of the growth inhibitor IGF-binding protein 3 by p53. Nature 377: 646-649

Busby, W. H., Klapper, D. G. and Clemmons D. R. (1988) Purification of a 31000 dalton insulin like growth factor binding protein from human amniotic fluid. J. Biol. Chem. 263: 14203-14210

Camacho-Hubner, C., McCusker, R. H. and Clemmons, D. R. (1991) Secretion and biological actions of insulin-like growth factor binding proteins in two human tumorderived cell lines in vitro. J. Cell. Physiol. 148: 281-289

Chan, S. J., Cao, Q. P. and Steiner, D. F. (1990) Evolution of insulin superfamily: cloning of a hybrid insulin/insulin-like growth factor cDNA from amphioxus. Proc. Natl. Acad. Sci. USA 87: 9319-9323

Cheung, P-T., Wu, J., Banach, W. and Chernausek, S. D. (1994) Glucocorticoid regulation of an insulin-like growth factor-binding protein- 4 protease produced by a rat neuronal cell line. Endocrinology 135: 1328-1335

Clemmons, D. R. and Gardner, L. I. (1990) A plasma factor is required for IGFBP-1 to potentiate DNA synthesis. J. Cell. Physiol. 145: 129-135

Cohen, P., Graves, H. C. B., Kamarei, M., Peehl, D. M. and Rosenfeld, R. G. (1991) Prostate specific antigen (PSA) is an IGF binding protein (IGFBP-3) protease found in seminal plasma. J. Clin. Endocrinol. Metab. 75: 1046-1053

Cohen, P., Lamson, G., Okajima, T. and Rosenfeld, R. G. (1993) Trans-fection of the human insulin-like growth factor binding protein-3 gene into Balb/c fibroblasts inhibits cellular growth. Mol. Endocrinol. 7: 380-386

Cohen, P., Peehl, D. M., Baker, B., Liu, F., Hintz, R. L. and Rosenfeld, R. G. (1994a) Insulin-like growth factor axis abnormalities in prostatic stromal cells from patients with benign prostatic hyperplasia. J. Clin. Endocrinol. Metab. 79: 1410-1415

Cohen, P., Peehl, D. M., Graves, H. C. B. and Rosenfeld, R. G. (1994b) Biological effects of prostate specific antigen as an insulin-like growth factor binding protein-3 protease. J. Endocrinol. 142: 407-415

Cohick, W. S., Gockerman, A. and Clemmons, D. R. (1993) Vascular smooth muscle cells synthesize two forms of insulin-like growth factor binding proteins which are regulated differently by the insulin-like growth factors. J. Cell. Physiol. 157: 52-60

Conover, C. A. (1991) Glycosylation of insulin like growth factor binding protein-3 (IGFBP-3) is not required for potentiation of IGF-I action: evidence for processing of cell bound IGFBP-3. Endocrinology 129: 3259-3268

Conover, C. A. and Kiefer, M. C. (1993) Regulation and biological effect of endogenous insulin-like growth factor binding protein-5 in human osteoblastic cells. J. Clin. Endocrinol. Metab. 76: 1153-1159

Conover, C. A., Kiefer, M. C. and Zapf, J. (1993) Posttranslational regulation of insulinlike growth factor binding protein-4 in normal and transformed human fibroblasts. $\mathrm{J}$. Clin. Invest 91: 1129-1137

Conover, C. A., Perry, J. E., Mulvihill, C. F. and Tindall, D. J. (1994) Endogenous cathepsin D-mediated hydrolysis of insulin-like growth factor binding proteins in cultured human prostatic carcinoma cells. Proc. 76th Annual Meeting Endocrine Soc., Abstr. 1052

Conover, C. A., Ronk, M., Lombana, F. and Powell, D. R. (1990) Structural and biological characterization of bovine insulin like growth factor binding protein-3. Endocrinology 127: 2795-2803

Culouscou, J. M., and Shoyab, M. (1991) Purification of a colon cancer cell growth inhibitor and its identification as an insulin-like growth factor binding protein. Cancer 


\section{Res. 51: 2813-2819}

Cornell, H. J., Embery, G. and Herington, A. C. (1986) Association of insulin like growth factors with metabolically inactive and active carrier bound complexes in sera. $\mathrm{J}$. Endocrinol. 241: 744-749

Daughaday, W. and Rotwein, P. (1989) Insulin-like growth factors I and II. Peptides, messenger ribonucleic acid and gene structures, serum and tissue concentrations. Endocr. Rev. 10: 68-91

Davenport, M. L., Pucilowska, J., Clemmons, D. R., Lundbald, R., Spencer, J. A. and Underwood, L. E. (1992) Tissue-specific expression of insulin-like growth factor-binding protein-3 protease activity during rat pregnancy. Endocrinology 130: 2505-2512

DeMellow, J. S. M. and Baxter, R. C. (1988) Growth hormone dependent insulin-like growth factor binding protein both inhibits and potentiates IGF-I stimulated DNA synthesis in skin fibroblasts. Biochem. Biophys. Res. Commun. 156: 199-204

Drop, S. L. S., Valiquette, G., Guyda, H. J., Corvol, M. T. and Posner, B. I. (1979) Partial purification and characterization of a binding protein for insulin-like activity (ILAs) in human amniotic fluid: a possible inhibitor of insulin-like activity. Acta Endocrinol. Copen. 90: 505-518

Durham, S. K., Kiefer, M. C., Riggs, B. L. and Conover, C. A. (1994) Regulation of insulin-like growth factor binding protein 4 by a specific insulin-like growth factor binding protein 4 proteinase in normal osteoblast like cells, implications in bone cell physiology. J. Bone Miner. Res. 9: 111-117

Elgin, R. G., Busby, W. H. and Clemmons, D. R. (1987) An insulin-like growth factor binding protein enhances the biologic response to IGF-I. Proc. Natl. Acad. Sci. USA 84: 3254-3258

Falkmer, S. (1985) Comparative morphology of pancreatic islets in animals. In The Diabetic Pancreas (Volk, B. W. and Arquilla, E. R., eds.), pp. 7-52, Plenum Press, New York

Fielder, P. J., Pham, H., Adashi, E. Y. and Rosenfeld, R. G. (1993) Insulin-like growth factors (IGFs) block FSH-induced proteolysis of IGF-binding protein-5 (BP-5) in cultured rat granulosa cells. Endocrinology 133: 415-418

Fielder, P. J., Thordarson, G., Talamantes, F. and Rosenfeld, R. G. (1990) Characterization of insulin-like growth factor binding proteins (IGFBPs) during gestation in mice, effects of hypophysectomy and an IGFBP specific serum protease activity. Endocrinology 127: 2270-2280

Frost, R. A. and Tseng, L. (1991) Insulin-like growth factor binding protein-1 is phosphorylated by cultured human endometrial stromal cells and multiple protein kinases in vitro. J. Biol. Chem. 266:18082-18088

Giudice, L. C., Farrell, E. M., Pham, H., Lamson, G. and Rosenfeld, R. G. (1990) Insulinlike growth factor biding proteins in maternal serum through-out gestation and in the puerperium, effects of a pregnancy-associated serum protease activity. J. Clin. Endocrinol. Metab. 71: 806-816

Gucev, Z., Oh, Y., Kelly, K. M. and Rosenfeld, R. G. (1995) Role of insulin-like growth factor binding protein (IGFBP)-3 in a retinoic acid (RA) and transforming growth factor $\beta$ (TGF- $\beta$ ) induced cell growth inhibition in MDA-231 human breast cancer cells. Proc. 77th Annual Meeting Endocrine Soc., p. 169, (Abs. \#1-225).

Guler, H. P., Zapf, J., Schmid, C. and Froesch, E. R. (1989) Insulin-like growth factors I and II in healthy man. Estimations of half-lives and production rates. Acta. Endocrinol. Copen. 121: 753-758

Hoeck, W. G. and Mukku, V. R. (1994) Identification of the major sites of phosphorylation in IGF binding protein-3. J. Cell. Biochem. 56: 262-273

Hossenlopp, P., Segovia, B., Lassare, C., Roghani, M., Bredon, M. and Binoux, M. (1990) Evidence of enzymatic degradation of insulin-like growth factor-binding proteins in the $150 \mathrm{~K}$ complex during pregnancy. J. Clin. Endocrinol. Metab. 71: 797-805

Imbenotte, J., Liu, L., Desauty, G. and Harel, L. (1992) Stimulation by TGF beta of chick embryo fibroblasts-inhibition by an IGFBP-3. Exp. Cell. Res. 199: 229-233

Jones, J. I. and Clemmons, D. R. (1995) Insulin-like growth factors and their binding proteins: biological actions. Endocr. Rev. 16: 3-33

Jones, J. I., Gockerman, A., Busby, W. H. Jr., Camacho-Hubner, C. and Clemmons, D. R. (1993b) Extracellular matrix contains insulin-like growth factor binding protein-5, potentiation of the effects of IGF-I. J. Cell. Biol. 121: 679-687

Jones, J. I., Gockerman, A., Busby, W. H. Jr., Wright, G. and Clemmons, D. R. (1993a) Insulin-like growth factor binding protein 1 stimulates cell migration and binds to the a5b1 integrin by means of its Arg-Gly-Asp sequence. Proc. Natl. Acad. Sci. USA 90: 10553-10557

Jones, J. I., D'Ercole, A. J., Camacho-Hubner, C. and Clemmons, D. R. (1991) Phosphorylation of insulin-like growth factor binding protein in cell culture and in vivo: effects on affinity for IGF-I. Proc. Natl. Acad. Sci. USA 88: 7481-7485

Kelley, K. M., Oh, Y., Gargosky, S. E., Gucev, Z., Matsumoto, T., Hwa, V., Ng, L., Simpson, D. M. and Rosenfeld, R. G. (1996) Insulin-like growth factor-binding proteins (IGFBPs) and their regulatory dynamics. Intl. J. Biochem. Cell Biol. 28: 619-637

Kiefer, M. C., Ioh, R. S., Bauer, D. M. and Zapf, J. (1991a) Molecular cloning of a new human insulin-like growth factor binding protein. Biochem. Biophys. Res. Commun. 176: 219-225

Kiefer, M. C., Masiarz, F. R., Bauer, D. M. and Zapf, J. (1991b) Identifi-cation and molecular cloning of two new $30-\mathrm{kDa}$ insulin-like growth factor binding proteins isolated from adult human serum. J. Biol. Chem. 266: 9043-9049

Kiefer, M. C., Schmid, C., Waldvogel, M., Schlapfer, I., Futo, E., Masiarz, F. R., Green, K., Barr, P. J. and Zapf, J. (1992) Characterization of recombinant human insulin-like growth factor-binding protein 4, 5 and 6 produced in yeast. J. Biol. Chem. 267: 1269212699

Kim, H-S., Nagalla, S. R., Oh, Y., Wilson, E. M., Roberts, C. T. Jr. and Rosenfeld, R. G. (1997) Synthesis and characterization of connective tissue growth factor (CTGF) as insulin-like growth factor-binding protein (IGFBP)-8. Proc. 79th Annual Meeting Endocrine Soc., p. 352, (Abs. \#P2-269)

Knauer, D. J. and Smith, G. L. (1980) Inhibition of biological activity of multiplication stimulating activity by binding to its carrier protein. Proc. Natl. Acad. Sci USA 77: 72527254

Koistinen, R., Itkonen, O., Selenius, P. and Seppala, M. (1990) Insulin-like growth factor-binding protein-1 inhibits binding of IGF-I on fetal skin fibroblasts but stimulates their DNA synthesis. Biochem. Biophys. Res. Commun. 173:408-415

Lamson, G., Pham, H., Oh, Y., Ocrant, I., Schwander, J. and Rosenfeld, R. G. (1989) Expression of the BRL-3A insulin-like growth factor binding protein ( $\mathrm{rBP}-30)$ in the rat central nervous system. Endocrinology 123: 1100-1102

Landau, D., Chin, E., Bondy, C., Domene, H., Roberts, C. T. Jr., Gronbaek, H., Flyvbjerg, A. and LeRoith, D. (1995) Expression of insulin-like growth factor binding proteins in the rat kidney, effects of long-term diabetes. Endocrinology 136: 1835-1842

LaTour, D., Mohan, S., Linkhart, T. A., Baylink, D. J. and Strong, D. D. (1990) Inhibitory insulin-like growth factor binding protein (hIGFBP-4): cloning, complete sequence and physiological regulation. Mol. Endocrinol.4: 1806-1814

Lee, K-O., Oh, Y., Guidice, L. C., Cohen, P. C., Peehl, D. M. and Rosenfeld, R. G. (1994) Identification of insulin-like growth factor-binding protein-3 (IGFBP-3) fragments and IGFBP-5 proteolytic activity in human seminal plasma, a comparison of normal and vasectomized patients. J. Clin. Endocrinol. Metab. 79: 1367-1372

Lee, P. D. K., Conover, C. A. and Powell, D. A. (1993) Regulation and function of insulin-like growth factor-binding protein-1. Proc. Soc. Expl. Biol. Med. 204: 4-29

Lee, Y-L., Hintz, R. L., James, P. M., Lee, P. D. K., Shively, J. E. and Powell, D. R. (1988) Insulin-like growth factor (IGF) binding protein complementary deoxyribonucleic acid from human HEP G2 hepatoma cells: predicted protein sequence suggests an IGF binding domain different from those of the IGF-I and the IGF-II receptors. Mol. Endocrinol. 2: $404-411$

Lewitt, M. S., Denyer, G. S., Cooney, G. J. and Baxter, R. C. (1991) Insulin-like growth factor-binding protein-1 modulates blood glucose levels. Endocrinology 129: 2254-2256 
Ling, N., Liu, X-J., Malkowski, M., Guo, Y-L., Erickson, G. F. and Shimasaki, S. (1993) Structural and functional studies of insulin-like growth factor binding proteins in the ovary. Growth Regul. 3: 70-74

Liu, L., Delbe, J., Blat, C., Zapf, J. and Harel, L. (1992) Insulin-like growth factor binding protein (IGFBP-3), an inhibitor of serum growth factors other than IGF-I and -II. J. Cell. Physiol. 153: 15-21

Martin, J. L. and Baxter, R. C. (1992) Insulin-like growth factor binding protein-3, biochemistry and physiology. Growth Regul. 2: 88-99

Martin, J. L. and Baxter, R. C. (1986) Insulin-like growth factor-binding protein from human plasma: purification and characterization. J. Biol. Chem. 261: 8754-8760

Martinerie, C., Viegas-Pequignot, E., Guenard, I., Dutrillaux, B., Nguyen, V. C., Bernheim, A. and Perbal, B. (1992) Physical mapping of human loci homologous to the chicken nov proto-oncogene. Oncogene 7: 2529-2534

Massague, J. and Czech M. P. (1982) The subunit structures of two distinct receptors for insulin-like growth factor I and II and their relationship to the insulin receptor. J. Biol. Chem. 257: 5038-5045

McCusker, R. H., Camacho-Hubner, C., Bayne, M. L., Cascieri, M. A. and Clemmons, D. R. (1990) Insulin-like growth factor (IGF) binding to human fibroblast and glioblastoma cells, the modulating effect of cell released IGF biding proteins (IGFBPs). J. Cell Physiol. 144: 244-253

Mohan, S., Bautista, C. M., Wergedal, J. and Baylink, D. J. (1989) Isolation of an inhibitory insulin-like growth factor (IGF) binding protein from bone cell-conditioned medium, a potential local regulator of IGF action. Proc. Natl. Acad. Sci. USA 86: 8338-8342

Murphy, M., Pykett, M. J., Harnish, P., Zang, K. D. and George, D. L. (1993) Identification and characterization of genes differentially expressed in meningiomas. Cell Growth Differ. 4: 715-722

Murray-Rust, J., McLeod, A. N., Blundell, T. L. and Wood, S. P. (1992) Structure and evolution of insulins, implications for receptor binding. BioEssays 14: 325-331

Nagamatsu, S., Chan, S. J., Falkmer, S. and Steiner, D. F. (1991) Evolution of the insulin gene superfamily. Sequence of a preproinsulin-like growth factor cDNA from the Atlantic hagfish. J. Biol. Chem. 266: 2397-2402

Nam, T. J., Busby, W. H. and Clemmons, D. R. (1994) Human fibroblasts secrete a serine protease that cleaves insulin-like growth factor-binding protein-5. Endocrinology 135: $1385-1391$

Neely, E. K. and Rosenfeld, R. G. (1992) Insulin-like growth factors (IGFs) reduce IGFbinding protein-4 (IGFBP-4) concentration and stimulate IGFBP-3 independently of IGF receptors in human fibroblasts and epidermal cells. Endocrinology 130: 985-993

Nonoshita, L. D., Wathen, N. C., Dsupin, B. A., Chard, T. and Guidice, L. C. (1994) Insulin-like growth factors (IGFs), IGF-binding proteins (IGFBPs), and proteolyzed IGFBP-3 in embryoic cavities in early human pregnancy, their potential relevance to maternal-embryonic and fetal interactions. J. Clin. Endocrinol. Metab. 79: 1249-1255

O'Brien, T. P., Yang, G. P., Sanders, L. and Lau, L. F. (1990) Expression of cyr61, a growth factor-inducible immediate-early gene. Mol. Cell. Biol. 10: 3569-3577

Oh, Y., Wilson, E. M., Kim, H-S., Yang, D. H., Rutten, M. J., Graham, D. L., Deveney, C. W., Hwa, V. and Rosenfeld, R. G. (1997) Regulation and biological action of IGFBP-7 in human breast cancer cells. Proc. 79th Annual Meeting Endocrine Soc., p. 351, (Abs. \#P2-267)

Oh, Y., Muller, H. L., Lamson, G. and Rosenfeld, R. G. (1993a) Insulin-like growth factor (IGF)-independent action of IGF-binding protein-3 in Hs578T human breast cancer cells. J. Biol. Chem. 268: 14964-14971

Oh, Y., Muller, H. L., Ng, L. and Rosenfeld, R. G. (1995) Transforming growth factor- $\beta$ induced cell growth inhibition in human breast cancer cells is mediated through insulinlike growth factor-binding protein-3 action. J. Biol. Chem. 270: 13589-13592

Oh, Y., Muller, H. L., Pham, H. and Rosenfeld, R. G. (1993b) Demonstration of receptors for insulin-like growth factor binding protein-3 on Hs578T human breast cancer cells. J. Biol. Chem. 268: 26045-26048

Oh, Y., Nagalla, S. R., Yamanaka, Y., Kim, H. S., Wilson, E. and Rosenfeld, R. G. (1996) Synthesis and characterization of insulin-like growth factor-binding protein (IGFBP)-7. J. Biol. Chem. 271: 30322-30325

Okazaki, R., Riggs, L. B. and Conover, C. A. (1994) Glucocorticoid regulation of insulinlike growth factor-binding protein expression in normal human osteoblast-like cells. Endocrinology 134: 126-162

Okajima, T., Iwashita, M., Takeda, Y., Sakamoto, S., Tanabe, T., Yasuda, T. and Rosenfeld, R. G. (1993) Inhibitory effects of insulin-like growth factor (IGF)-binding protein-1 and -3 on IGF-activated glucose consump-tion in mouse BALB/C 3T3 fibroblasts. J. Endocrinol. 136: 457-470

Rechler, M. M. (1993) Insulin-like growth factor binding proteins. Vitam. Horm. 47: 1-114 Reeve, J. G., Schwander, J. and Bleehen, N. M. (1993) IGFBP-2: an important regulator of insulin like growth factor action in human lung tumors. Growth Regul. 3: 82-84

Rinderknecht, E. and Humbel R. E. (1978) The amino acid sequence of human insulinlike growth factor I and its structural homology with proinsulin. J. Biol. Chem. 253: 27692776

Rodgers, B. D., Strack, A. M., Dallman, M. F., Hwa, L. and Nicoll, C. S. (1995) Corticosterone regulation of insulin-like growth factor (IGF)-I, IGF binding proteins and growth in streptozotocin-diabetic rats. Diabetes 44:1420-1425

Rohan, R. M., Ricciarelli, E., Kiefer, M. C., Resnick, C. E. and Adashi, E. Y. (1993) Rat ovarian insulin-like growth factor-binding protein-6, a hormonally regulated thecainterstitial-selective species with limited antigonadotropic activity. Endocrinology 132: 2597-2512

Rosenfeld, R. G., Pham, H., Cohen, P., Fielder, P., Gargosky, S. E., Muller, H., Nonoshita, L. and Oh, Y. (1994) Insulin-like growth factor binding proteins and their regulation. Acta. Paediatr. Suppl. 339: 154-158

Rosenfeld, R. G., Pham, H., Conover, C. A., (1989) Structural and im-munological comparison of insulin-like growth factor (IGF) binding proteins of cerebrospinal and amniotic fluids. J. Clin. Endocrinol. Metab. 68: 636-646

Rosenfeld, R. G., Pham, H., Oh, Y., Lamson, G. and Guidice L. C. (1990) Identification of insulin-like growth factor binding protein-2 (IGF-BP-2) and a low molecular weight IGF-BP in human seminal plasma. J. Clin. Endocrinol. Metab. 70: 551-553

Rotwein, P. (1991) Structure, evolution, expression and regulation of insulin-like growth gactors I and II. Growth Factors 5: 3-18

Scharla, S. H., Strong, D. D., Mohan, S., Baylink, D. J. and Linkhart, T. A. (1991) 1,25dihydroxyvitamin D3 differentially regulates the production of IGF-I and IGFBP-4 in mouse osteoblasts. Endocrinology 129: 3139-3146

Schmid, C., Ernst, M., Zapf, J. and Froesch, E. R. (1989) Release of insulin-like growth factor carrier proteins by osteoblasts, stimulation by estradiol and growth hormone. Biochem. Biophys. Res. Commun. 160: 788-794

Schmid, C., Rutishauser, J., Schlapfer, I., Froesch, E. R. and Zapf, J. (1991) Intact but not truncated insulin-like growth factor binding protein-3 (IGFBP-3) blocks IGF---induced stimulation of osteoblasts: control of IGF signalling to bone cells by IGFBP-3-specific proteolysis? Biochem. Biophys. Res. Commun. 179: 579-585

Shimasaki, S., Shimonaka, M., Zhang, H.-P. and Ling, N. (1991) Identifi-cation of five different insulin-like growth factor binding proteins (IGFBPs) from adult rat serum and molecular cloning of a novel IGFBP-5 in rat and human. J. Biol. Chem. 266: 1064610653

Shimasaki, S. and Ling, N. (1991) Identification and molecular charac-terization of insulin-like growth factor binding proteins (IGFBP-1,-2,-3,-4,-5 and -6). Prog. Growth Factor Res. 3: 243-266

Sommer, A., Spratt, S. K., Tatsuno, G. P., Tressel, T., Lee, R. and Maack, C. A. (1992) Properties of glycosylated and nonglycosylated human recombinant IGF binding protein-3 (IGFBP-3). Growth Regul 3: 46-49 
Swisshelm, K., Ryan, K., Tsuchiya, K. and Sager, R. (1995) Enhanced expression of an insulin growth factor-like binding protein (mac25) in senescent human mammary epithelial cells and induced expression with retinoic acid. Proc. Natl. Acad. Sci. USA 92: $4472-4476$

Thissen, J.-P., Ketelslegers, J.-M. and Underwood, L. E. (1994) Nutritional regulation of the insulin-like growth factors. Endocrine Rev. 15: 80-101

Ui, M., Shimonaka, M., Shimasaki, S. and Ling, M. (1989) An insulin-like growth factorbinding protein in ovarian follicular fluid blocks follicle-stimulating hormone-stimulated steroid production by ovarian granulosa cells. Endocrinology 125: 912-916

Villaudy, J., Delbe, J., Blat, C., Desauty, G., Golde, A. and Harel, L. (1991) An IGF binding protein is an inhibitor off FGF stimulation. J. Cell. Physiol. 149: 492-496

Westwood, M., Gibson, J. M., Davies, A. J., Young, R. J. and White, A. (1994) The phosphorylation pattern of insulin-like growth factor-binding protein-1 in normal plasma is different from that in amniotic fluid and changes during pregnancy. J. Clin. Endocrinol. Metab. 79: 1735-1741

Wilson, E. M., Oh, Y. and Rosenfeld, R. G. (1997) Generation and characterization of an IGFBP-7 antibody: Idetification of 31 kD IGFBP-7 in human biological fluids and Hs578T human breast cancer conditioned media. J. Clin. Endocrinol. Metab. 82: 13011303

Wood, T. L., Streck, R. D. and Pintar, J. E. (1992) Expression of the IGFBP-2 gene in post-implatation rat embryos. Development 114: 59-66

Wood, W. L., Cachianes, G., Henzel, W. J., Winslow, G. A., Spencer, S. A., Hellmiss, R., Martin J. L. and Baxter, R. C. (1989) Cloning and expression of the growth hormonedependent insulin-like growth factor-binding protein. Mol. Endocrinol. 2: 1176-1185

Zapf, J., Schoenle, E., Jagars, G., Sand, I., Grunwald, J. and Froesch, E. R. (1979) Inhibition of the action of nonsuppressible insulin-like activity on isolated fat cells by binding to its carrier protein. J. Clin. Invest. 63: 1077-1084

Zhou, J., Dsupin, B. A., Giudice, L. C. and Bondy, C. A. (1994) Insulin-like growth factor system gene expression in human endometrium during the menstrual cycle. J. Clin. Endocrinol. Metab. 79: 1723-1734 